\title{
At Home: Family reintegration of trafficked Indonesian men
}

\author{
Rebecca Surtees
}

\begin{abstract}
Large numbers of Indonesian men migrate each year for work in construction, in factories and in agriculture, on plantations and on fishing boats. Many of them end up exploited in ways that constitute human trafficking, suffering violence, deprivation, restricted freedom and severe exploitation as well as long periods of separation from their families. This article explores the challenges faced by forty-nine Indonesian men reintegrating into their families and communities after having been trafficked. While many problems with the family were caused by economics, tensions also resulted from long separations, fractured relationships, and frustration and blame over 'failed' migration and unfulfilled expectations. Tensions were sometimes exacerbated when men faced recrimination and blame in their communities after return. Understanding the nature of and reasons for the problems that men faced after trafficking is vital in considering how trafficked men and their families can be supported to recover and reintegrate after trafficking.
\end{abstract}

Keywords: human trafficking, men, reintegration, Indonesia, family, community

Please cite this article as: R Surtees, 'At Home: Family reintegration of trafficked Indonesian men', AntiTrafficking Review, issue 10, 2018, pp. 70-87, www.antitraffickingreview.org

\section{Introduction}

Male migration is an important economic strategy in Indonesia. Men migrate for work both within the country as well as abroad, often irregularly to neighbouring countries like Malaysia to work in construction and on plantations. Migration for some labour sectors, like fishing and factory work, involves formal, regular migration channels and often more distant destinations.

Indonesian men's experiences of migration are diverse. Although not inevitable, these migration patterns may lead to exploitation, abuse and even human trafficking. ${ }^{1}$ Many find work and return home with money; many others are unpaid or under-paid, poorly treated and exploited. ${ }^{2}$ The extent to which these latter instances rise to the level of human trafficking remains unclear. Moreover, migrants may experience both success and exploitation along the same migration trajectory. ${ }^{3}$ Nonetheless, what is increasingly clear is that some (and arguably many) Indonesian men are trafficked for different forms of labour. ${ }^{4}$

1 Indonesia's anti-trafficking law prohibits all forms of human trafficking, including for labour exploitation. Republic of Indonesia (2007), Law on the Eradication of the Criminal Act of Trafficking in Persons, Number 21, Year 2007, Article 1.

2 M Eilenberg, 'Territorial Sovereignty and Trafficking in the Indonesia-Malaysia Borderlands' in M Ford, L Lyons and W van Schendel (eds.), Labour Migration and Human Trafficking in Southeast Asia: Critical perspectives, Routledge, London, 2012, p. 121; O Pye, R Daud, Y Harmono and Tatat, 'Precarious Lives: Transnational biographies of migrant oil palm workers', Asia Pacific Viewpoint, vol. 53, issue 3, 2012, pp. 338-340; IOM, Labour Migration from Indonesia: An overview of Indonesian migration to selected destinations in Asia and the Middle East, IOM, Jakarta, 2010, p. 47.

3 M Ford and L Lyons, 'Labor Migration, Trafficking and Border Controls' in T Wilson and H Donnan (eds.), $A$ Companion to Border Studies, Wiley-Blackwell Publishing, Chichester, 2012, pp. 439-440.

4 R Fuchs, Human Trafficking of Legal and Illegal Migrant Workers in Taiwan, Hope Workers' Center, Taiwan, 2011; IOM, Report on Human Trafficking, Forced Labour and Fisheries Crime in the Indonesian Fishing Industry, IOM, Jakarta, 2016; J Joudo Larsen, H Andrevski and S Lyneham, 'Experiences of Trafficked Persons: An Indonesian sample', Trends \& Issues in Crime and Criminal Justice, no. 449, 2013; S Lyneham and J Joudo Larsen, 'Exploitation of Indonesian Trafficked Men, Women and Children and Implications for Support', Trends \& Issues in Crime and Criminal Justice, no. 450, 2013; C Stringer, G Simmons, D Coulston and DH Whittaker, 'Not in New Zealand's Waters, Surely? Linking labour issues to GPNs', Journal of Economic Geography, vol. 14, 2014, pp. 745-748; R Surtees, Our Lives: Vulnerability and resilience among Indonesian trafficking victims, NEXUS Institute, Washington, DC, 2017; R Surtees, LS Johnson, T Zulbahary and SD Caya, Going Home: Challenges in the reintegration of trafficking victims in Indonesia, NEXUS Institute, Washington, DC, 2016. 
They are trafficked for work in construction, in factories and in agriculture, on plantations and on fishing boats, suffering violence, deprivation, restricted freedom and severe exploitation. They also suffer separation from their families, whom they are unable to contact. These situations last for months and even years and returning home marks a turning point in these men's lives. And yet being 'at home' is not uncomplicated.

This article explores the experiences and challenges faced by forty-nine Indonesian men as they reintegrated into their families and communities after having been trafficked. Many tensions within the family were caused by economics, linked to migration debt and having returned without money. But tensions were also the result of long separations that fractured family relationships, as well as frustration and blame over 'failed' migration and unfulfilled expectations. Tensions were sometimes compounded by recrimination and stigma coming from friends and neighbours within the community.

While family was an important source of support for many men after trafficking, the family environment also involved vulnerabilities and tensions that inhibited or undermined recovery and reintegration. Moreover, expectations around men's roles-as husbands, fathers and sons-meant that experiences of reintegration differed, in some ways, from the experiences of trafficked women.

Experiences of long-term reintegration, particularly men's experiences, are largely missing from research on human trafficking in Indonesia ${ }^{5}$ (and indeed more widely), and yet understanding these experiences is key to our ability to design and implement tailored and effective reintegration programmes and policies. Also missing is an understanding of the nature of and reasons for tensions within men's families and communities after trafficking and over the course of their post-trafficking lives. These experiences need to be better understood to ensure more effective identification and assistance of Indonesian men and the support needed to recover and reintegrate after trafficking. This is particularly pressing when support provided by the family may be the only assistance available to trafficked men in their lives after trafficking, and when community dynamics may, in some cases, undermine their reintegration.

\section{Research Approach and Data Collection}

This paper is based on in-depth interviews with forty-nine trafficked men conducted between September 2014 and April 2016. ${ }^{6}$ Twenty-four of these men were interviewed a second time, between six to nine months after their first interview. The research team also maintained informal contact with seven of the men between interviews (e.g. in-person meetings, text messages and Facebook) and with three men beyond the end of the project. Interviews were conducted in Bahasa Indonesia by two Indonesian researchers, using standardised questionnaires and tailoring lines of inquiry to individual experiences, before being transcribed and translated into English. All interviews and field notes were cleaned, coded and entered into the qualitative data analysis software NVivo 10. Data was analysed following the principles of thematic analysis. ${ }^{7}$

Research was conducted in the communities where men were integrating or reintegrating. We selected villages where we had a working relationship with authorities or civil society. Potential respondents were first approached by NGO staff, a community leader or a migrant worker activist, who explained the study and provided a written project description. Respondents were then given time to decide whether to participate in the research. Interviews were conducted in a location chosen by the respondent and began with a detailed process of seeking informed consent. Following the interview, the researcher provided each respondent with

5 S Lyneham, 'Recovery, Return and Reintegration of Indonesian Victims of Human Trafficking', Trends \& Issues in Crime and Criminal Justice, no. 483, 2014; R Surtees, 'Being Home: Exploring family reintegration among trafficked Indonesian domestic workers' in R Piotrowicz, C Rijken and BH Uhl (eds.), Routledge Handbook of Human Trafficking, Florence, 2017; $\mathrm{R}$ Surtees, Moving On: Family and community reintegration among Indonesian trafficking victims, NEXUS Institute, Washington, DC, 2017; R Surtees, Our Lives; R Surtees et al., Going Home.

6 Data was collected for NEXUS Institute's research on reintegration in Indonesia, funded by the US Department of State. The research team included myself, Thaufiek Zulbahary, Suarni Daeng Caya, Laura S. Johnson and Pattarin Wimolpitayara. The project was overseen by Stephen Warnath. Thanks to Stephen Warnath, Laura S. Johnson and Thaufiek Zulbahary who reviewed and provided feedback on this article.

7 J Aronson, 'A Pragmatic View of Thematic Analysis', The Qualitative Report, vol. 2, issue 1, 1994; V Braun and V Clarke, 'Using Thematic Analysis in Psychology', Qualitative Research in Psychology, vol. 3, 2006. 
referral information, explaining assistance options and how to access them. We reimbursed transportation and meal costs and provided a small gift ${ }^{8}$ in recognition of the respondent's contribution to the research. Researchers contacted respondents after several months to be re-interviewed and, if they agreed, the above process was repeated.

We also conducted interviews with 144 key informants, primarily government and NGO service providers (social workers, social assistants, psychologists, lawyers, paralegals and medical personnel) but also administrators, policy makers, law enforcement, migrant worker activists and village leaders.

\section{About Our Respondents}

The men —all adult at the time of interview—ranged in age from 16 to 49 when trafficked. Almost half were between 18 and 29 years old; 20 men were 30 to 39 years old and four were between 40 and 49 years old. One had been trafficked for construction work at the age of 16 , but interviewed when adult.

Most men were married (29 of 49) and had one or two children; four had three or more children. One man was divorced with children. A significant minority were unmarried (19 of 49) and without children.

Trafficked men's family situations changed after trafficking. Twenty-six (of 29) married men remained married after trafficking but a handful reported severe marital problems verging on divorce. Two men divorced their wives after returning home.

Eleven (of 19) unmarried men were still unmarried when interviewed. Eight of them married after trafficking. Not all of these marriages lasted: one man divorced his wife within two years; another married and divorced three times in the years after his return; and one married upon his return, divorced his wife within months and remarried.

Most men (35) were ethnically Javanese, eleven were Sundanese and three were Bugis. ${ }^{9}$ They originated from West Java $(n=27)$, Jakarta $(n=1)$, Central Java $(n=15)$, South Sulawesi $(n=3)$, East Java $(n=1)$ and Lampung $(\mathrm{n}=2)$. Most returned home after trafficking; however, some lived in new locations-staying temporarily in Jakarta or other towns while working, or integrating in Jakarta or a new village.

Men had been trafficked for fishing (32), plantation work (8), factory work (4), construction (3) and commercial cleaning (2). Recruitment was most commonly through formal migration channels. Most often, recruiters contacted men in their home communities and facilitated their contact with recruitment agencies. They signed contracts with promised monthly wages of between USD 100 and USD 600, well above Indonesia's minimum wage. ${ }^{10}$ They paid high recruitment fees, ranging from USD 100 to USD 1,360—often borrowing money to fund their migration. ${ }^{11} \mathrm{~A}$ minority of men $(\mathrm{n}=10)$ migrated irregularly, for example, to nearby Malaysia, but nonetheless incurred debt to recruiters and agencies and for transportation.

Living conditions while trafficked, regardless of the form of exploitation, were inadequate and substandard. Men trafficked for construction and plantation work generally lived at the worksite. Sleeping quarters were crowded, uncomfortable and often without beds. Living conditions on fishing vessels were unhygienic and

8 Sembako (sembilan baban pokok) or the nine necessities for daily life (rice, sugar, fuel, salt, salted fish, cooking oil, coffee, eggs and flour).

9 Javanese and Sundanese are the two largest ethnic groups, comprising $40 \%$ and $15 \%$ of the population respectively, with strong cultural similarities. A Anata et al., Changing Ethnic Composition: Indonesia 2000-2010, International Union for the Scientific Study of Population, Paris, 2013, pp. 7-14; R Hefner, 'Java’s Five Regional Cultures' in E Oey (ed.), Java, Periplus Editions, Indonesia, 1997. Bugis comprise the largest ethnic group in South Sulawesi.

10 Indonesian men recruited onto fishing vessels in New Zealand were promised salaries of USD 200 to USD 500 per month. G Simmons and C Stringer, 'New Zealand's Fisheries Management System: Forced labour an ignored or overlooked dimension?', Marine Policy, vol. 50, 2014, p. 76.

11 Indonesian male migrants generally pay recruitment fees up front (borrowing money at high interest rates); women usually have their salary deducted once abroad. J Lindquist, 'Labour Recruitment, Circuits of Capital and Gendered Mobility: Reconceptualizing the Indonesian migration industry', Pacific Affairs, vol. 83, 2010, pp. 125-128. See also Fuchs, p. 8; IOM, Report on Human Trafficking, Forced Labour and Fisheries Crime in the Indonesian Fishing Industry, p. 62; Stringer et al., 'Not in New Zealand's waters, surely?'. 
confined, with shared beds and bedclothes. Trafficked men generally received insufficient and poor-quality food and limited access to drinking water. Those trafficked on fishing boats worked from ten to twenty-four hours each day; one third of these men worked over twenty hours each day. Men trafficked for factory work, construction and palm oil plantations worked shifts of twelve hours, with one man working up to twenty hours each day in a factory. They seldom had protective equipment or suitable clothing, in spite of working in hazardous conditions and intense climates. Rest was limited and often came during brief intervals with regular interruptions. Most trafficking victims did not have any holidays or days off. Violence (physical and psychological) was common. ${ }^{12}$ Two men reported sexual violence. ${ }^{13}$

Men trafficked for fishing were exploited in Trinidad and Tobago (9), South Africa (7), Taiwan (5), Ghana (5), South Korea (4), Mauritius (1) and Uruguay (1). Men trafficked for construction were exploited in Singapore (2) and Malaysia (1); for plantation work in Malaysia (7) and Indonesia (1), for factory work in Malaysia (2) and Taiwan (2) and for commercial cleaning in Singapore (1) and Malaysia (1). Some men were exploited in multiple destinations.

\section{Returning Home}

Family is the central structure of Sundanese and Javanese societies. Family members owe each other attention, care and various other mandatory obligations; neglecting familial obligations is a serious social infraction. ${ }^{14}$ For most men, family obligations — as fathers, husbands and sons—led them to migrate for work, ${ }^{15}$ and family was their primary source of support during reintegration after trafficking. ${ }^{16}$ Men's family situations, therefore, had significant implications for reintegration outcomes and, in many cases, accounted for at least some (if not many) of the 'ups and downs' experienced during their post-trafficking lives.

The men we interviewed reintegrated into different family and household constellations. Residence patterns among Sundanese and Javanese are largely governed by choice and are often determined by availability of housing and income. ${ }^{17}$ Married men often returned to live with their wives and children $(n=12)$. Some of the married respondents $(\mathrm{n}=17)$, though, lived in extended family settings, with parents or parents-in-law. Some men shared their own homes with parents or parents-in-law, but more commonly, they lived in their parents' or parents-in-law's houses, which, arguably, left them more open to criticism from parents and in-laws on whom they depended.

Nineteen respondents were unmarried and had no children when trafficked. Of these, ten returned to live with their parents, five were living in temporary housing and four were living with siblings or extended family members.

The following sections explore the interplay of economic issues and relationships within the family after return from trafficking. These tensions, often coterminous and mutually reinforcing, were sometimes exacerbated by gossip and recriminations in the community. And while 'failed' migrants may face similar issues after return,

12 See also Lyneham and Larsen, p. 2; Simmons and Stringer, pp. 76-77; Stringer et al., 'Not in New Zealand's waters, surely?'; Surtees, Our Lives.

13 Sexual violence against trafficked men has also been documented in other research. See Global Freedom Center, Overlooked: Sexual violence in labor trafficking, Global Freedom Center, California, 2012; L Kiss et al., 'Health of Men, Women, and Children in Post-Trafficking Services in Cambodia, Thailand, and Vietnam: An observational crosssectional study', Lancet Global Health, vol. 3, 2015; Stringer et al., 'Not in New Zealand's waters, surely?'; Surtees, Our Lives; R Surtees, In African Waters: The trafficking of Cambodian fishers in South Africa, NEXUS Institute and IOM, Washington, DC and Geneva, 2014.

14 H Geertz, The Javanese Family: A study of kinship and socialization, The Free Press, Glencoe, 1961; Koentjaraningrat (ed.), Villages in Indonesia, Cornell University Press, New York, 1967.

15 Indonesian men's position as primary breadwinner and head of the household was entrenched in the 1974 Marriage Law. Republic of Indonesia (1974) Law on Marriage, Number 1, Year 1974, paragraph 31.

16 Indonesia's anti-trafficking law provides for temporary shelter, medical and social rehabilitation, return assistance and social reintegration. However, trafficked men received either short-term assistance or no assistance at all, with limited assistance available in home villages. Surtees et al., Going Home.

17 L Dube, 'Kinship and Gender in South and Southeast Asia: Patterns and contrasts', 9th J.P. Naik Memorial Lecture, 1994. 
some of the specific features of human trafficking further complicated men's lives and relationships once home, including the impact of exploitation and the damage of long separations without contact.

\section{Coming home without money, coping with migration debt}

The need for money/income is the main driver for most Indonesian men who migrate for work (including those who end up trafficked) - for example, to build or repair a home, buy land, pay school fees for children and to cover daily living needs. ${ }^{18}$ Yet most of our respondents were unable to remit or return with money, contrasting with many male migrants who succeeded to varying degrees. Moreover, most had also incurred substantial migration debt, paying recruitment fees as high as IDR 15 million (USD 1,360). ${ }^{19}$ This was a source of considerable stress for all men. For married men with children, as household heads and primary breadwinners, economic considerations were particularly prominent. A man's responsibility to support his wife and children - and 'failure' of trafficked men to do so-was a central tension in their lives and families after trafficking. Wives also suffered as a result; consistent with other research on Indonesian migrants which found that predictability and regularity of remittances influenced stress levels and mental well-being of carers left behind. ${ }^{20}$

Wives often went into debt to care for children in the absence of remittances. As one man explained: 'My wife gave me a list containing notes about the debts. [She said], "This is the amount during the months you left" ... All the needs were written down by my wife. ... The total was IDR 4.5 million (USD 409).' They also struggled to care for their families once home. One man described how tension with his wife was a direct function of whether he provided money for his family: 'If I don't have money [my wife] will be angry at me. [She says], "We need to buy rice. What can we eat tomorrow?" ... [If I don't work] she will be angry. But if I have money, she will not be angry at me.'

Financial problems also impacted men's relations with parents and parents-in-law. One man's parents had sold their land to cover his migration debt and when he came home without money, they refused to see him.

Failed migration meant that the man's parents (or parents-in-law) had to support him and, commonly, also his family. One man, in debt to his parents for migration costs, was living in their home with his wife and their son, and the environment was tense: 'My mother makes a fuss if my boy watches the TV, like, "Buy your own TV'. She often tries to kick me out of the house.' He went on to explain that money was a constant issue in the household: 'On Sundays, talk about the debt to my parents always came up ... How could I pay it off quickly? Saving IDR 100,000 (USD 9) already took ten days so it was a slow process ... We argued constantly.' He spoke of worsening relations with his mother over time because of his debt:

[Family relations] are worse now. ... At first my mother understood this unfortunate event. But now she always demands that the debt be paid. And she always tries to kick us out of the house. So, it's always in my thoughts. I couldn't help but think how a parent could do that to her son, daughter-inlaw and grandson. I seem calm but I'm under pressure.

Some economic problems (and, thus, family tension) endured for years, as one man explained: 'Harmony is possible only if there is enough to cover for one's family needs. ... When my children asked for money, [my wife] yelled and asked them to go to me for the money. It was understandable considering I didn't provide for my family.'

Economic issues were also a source of tension for unmarried men, particularly those whose families needed support. Some unmarried men, though, faced less pressure and were cared for by parents. One father migrated shortly after his son's return, to support him while he recovered from his exploitation.

18 G Hugo, 'International Labor Migration and the Family: Some observations from Indonesia', Asian and Pacific Migration Journal, vol. 4, issue 2-3, 1995, pp. 290-292; Surtees, Our Lives.

19 The exchange rate (1 USD = 11,000 IDR) is the average exchange rate from 2010-2017.

20 E Graham, LP Jordan and BSA Yeoh, 'Parental Migration and the Mental Health of Those who Stay Behind to Care for Children in South-East Asia', Social Science \& Medicine, vol. 132, 2015, pp. 225-235. 
Economic considerations prevented some men from returning home. Some worked temporarily in Jakarta or other districts to earn money to send home or with which to return to their families. By contrast, and with few exceptions, Indonesian women trafficked for labour (domestic work), returned to their families, even without money or in debt. ${ }^{21}$

Some men could not return home because they were unable to repay their migration debt, as one explained: 'I do not have the courage to go home because I have debt. I have debt to my relative for IDR 30 million (USD 2,727). ... My family cries each time I call. They want to see me but I do not want to go home because I cannot face my relative. I am ashamed.'

That being said, money was not always a source of conflict, even in dire economic situations. One man described family support in spite of a weak family economy:

Alhamdulillah [thank God] there's no problem ... [My wife] worries about what to eat the next day when we're short on cash. Sometimes she borrows money if I haven't gotten any job. [My wife and parents-in-law], we stick together whether there is something to eat or there isn't. No, they never [get angry].

\section{Reactions and relationships within the family. Reuniting with wives, children and extended family}

While, on the surface, much tension was about money, it was often as much about having 'failed' (as husband, father, son). Economic problems served to highlight unfulfilled expectations, which led, at times, to disappointment, blame and recrimination. Trafficking separations also created emotional distance between men and their families. Even in generally happy family settings, there was strain and tension. Feelings of relief, gratitude and happiness at return often gave way in the face of these pressures.

The impact of trafficking — being stressed, traumatised, physically unwell—-meant that men acted and reacted in ways that upset family members, creating further distance and amplifying resentment. One man described being stressed after his return: 'My feeling was like getting fed-up. Annoyed. Wanting to get angry but at whom, I asked. I was confused.'

At the same time, many men often kept some (or most) details of their exploitation secret, as one explained: 'I didn't tell [my wife]. I don't want to make my wife sad. ... [I did not tell her] the terrible things I experienced in the deep sea.' Not knowing about men's exploitation meant families did not understand their difficult or erratic behaviours, leading to feelings of frustration, disappointment and anger.

The following sections explore the tensions in men's family relationships with wives, children and parents, tensions that stand in sharp contrast to the Javanese ideal of family, which offers tentrem (peace), hangat (emotional warmth) and kasib sayang (unconditional love and giving). ${ }^{22}$

\section{Relationships with wives}

Reuniting with their wives was an important moment for most married men. Wives too were happy and grateful at their husbands' return. One man explained how his wife supported and encouraged him over the two and half years that he had been home: 'She often comforts me by saying not to think too much about the debt, take care of my own health. Debt will be settled eventually, she said.'

Nonetheless, problems emerged in marriages after trafficking. Some were 'minor', predictable and manageable tensions. Very commonly, though, tensions were deep-seated and intractable. Marital problems were, on the surface, a function of men's inability to support their families. But closer examination suggests that this was as much about the toll that trafficking separation took on their wives and marital relationships. Lack of communication while away was a source of considerable stress and resentment. One man described his wife's loneliness while he was away: 'My wife did not communicate with me for a year. In the meantime, life was

21 Surtees, 'Being Home'.

22 M Subandi, 'Family Expressed Emotion in a Javanese Cultural Context', Culture, Medicine and Psychiatry, vol. 35, issue 3, 2011. 
going on ... she could not send messages because I was on the sea. So she entertained herself not with me, but with the children only.' Another man explained that his marriage had been happy, but lack of contact while trafficked, amplified by no remittances, meant that it was now on the verge of collapse: '[After my return], I kept working and tried to provide for the family but my wife felt that it wasn't enough. We often argued. She felt that during my three years away I never gave her updates or money. My family even thought I was dead since they never heard from me for two and a half years.'

This is consistent with research on migration from Indonesia, which found stay-behind adults faced health issues, including psychosocial distress. ${ }^{23}$ Another study, which included Indonesia, found that absence without contact, especially when prolonged and seemingly without reason, breached transnational family relations and negatively impacted the psychological well-being of stay-behind carers. ${ }^{24}$ Infrequent contact with the migrant husband and not receiving remittances was commonly associated with mental health disorders among staybehind mothers. ${ }^{25}$

Marital problems increased relative to the period of separation and level of contact while away. One man, whose wife was supportive, was away only for a few months. By contrast, lack of contact for years damaged and even destroyed marriages. One man explained how, when his friend managed to call home while trafficked, his wife demanded a divorce:

[He was] bones only, he was so tiny when he [was] pulled out of the float. He cried a lot in my lap, 'Please tell the captain, I want to go home.' ... He had a chance to make a phone call and what he heard over the phone [from his wife] was, 'I want to divorce.' [He was] already neglected over there, no salary, even fighting over food. He got a phone call from his wife, asking to divorce.

Another source of tension was men's failure, as one man found in his wife's reaction and blame: '[I said] "I am a failed person. When I fail, you should support me. Let's do it together. One of us fails it means all of us fail." ... Then she said, "The one who failed is you, right?" He expressed disappointment at her lack of support when he 'failed': 'When I was successful ... we went through it together. Why, when I am down, I am alone?'

Some wives worried that their husbands had spent money frivolously or had relationships with other women while abroad. One man described a troubled relationship with his wife over many months because of this concern: 'There were many quarrels with my wife ... I returned home without any money. She thought ... that I was having fun abroad.' Although he explained what happened, she vacillated between acceptance and recrimination: 'I told her everything, but that's my wife. At times she would understand. At other times, she would remember the neighbours saying things about me. ... It's difficult for her to trust me one hundred per cent.'

Such tensions were often triggered or exacerbated by blame and recrimination from neighbours. Men faced accusations of not working hard, having affairs and/or wasting their salary, which in turn led to doubt in the minds of family members, as one man explained:

'[The neighbours] didn't say it directly to me. They said it to my wife, "Ah, your husband must have become a drunkard abroad, a womaniser, that's why he returned without any money." So automatically my wife had the same opinion. Finally, I was to blame. Even though I had explained, I was to blame.'

Another source of community criticism was when men had spent time 'in prison' (i.e. in detention as irregular migrants abroad). One man described facing insults and blame from neighbours, making him feel ashamed in front of his wife: '[After trafficking] the hardest challenge was the insults of people, neighbours. ... My wife cried after going to the store. ... They said, "Why did you go away? You did not get any money and you were in

23 Y Lu, 'Household Migration, Social Support, and Psychosocial Health: The perspective from migrant-sending areas', Social Science \& Medicine, vol. 74, 2012.

24 E Graham et al., 'Transnational Families and the Family Nexus: Perspectives of Indonesian and Filipino children left behind by migrant parent(s)', Environment and Planning, vol. 44, issue 4, 2012.

25 Graham, Jordan and Yeoh, 'Parental Migration and the Mental Health of Those who Stay Behind to Care for Children in South-East Asia'. 
prison." I was ashamed. Everyone knew ... it was a burden to me, to my family. What did I do there that I went to prison?'

Not all community reactions were negative, as one man explained: '[My friends and neighbours] welcomed me well ... "Are you well?" “Thank God, I am well." "It's good we could meet again.” To some extent acceptance without censure may be a function of neighbours' knowledge of the 'real situation' when abroad, as the same man observed: 'The majority in this village ... even though they do not go abroad, they know because they sailed also. Most of the people here already understood.'

\section{Relationships with children}

A father's responsibility to support his child(ren) is a central contributor, if not primary catalyst, in the decision to migrate for a large number of men, including those who are trafficked. One man explained his motivation: 'When my children wanted to enrol in school, this made me have to go fishing.'

Most children of trafficked fathers $(n=28)$ lived with their mothers in their fathers' absence. ${ }^{26}$ In contrast to trafficked mothers, returning men were seemingly less likely to be blamed and rejected by their children, and spoke less often about damage to their relationship with children left behind. ${ }^{27}$ Men's migration absence was often seen as part of their 'normal' role as the family breadwinner, further normalised by the prominence of labour migration as a household strategy. ${ }^{28}$ One man described how his daughter was initially shy with him but quickly things returned to 'normal'. By contrast, children of trafficked mothers experienced their mother's absence, in many cases, as abandonment and neglect. ${ }^{29}$

Nonetheless, children were affected by their father's absence. Staying in touch with children is one means by which migrant parents maintain and preserve their parental role. ${ }^{30}$ And recent migration research has identified a range of negative impacts for families left behind when regular communication is not maintained, ${ }^{31}$ including, in one study in Indonesia, a deficit in children's subjective well-being. ${ }^{32}$ Most trafficked men struggled to maintain contact with their children, with limited or no access to means of communication. ${ }^{33}$ Remittances from

26 Mothers were principal carers for most children with migrant fathers; carers of children of migrant mothers made greater use of non-parental care. Graham et al., 'Transnational Families and the Family Nexus'.

27 Surtees, 'Being Home'. See also A Brunovskis and R Surtees, No Place like Home? Challenges in family reintegration after trafficking, Fafo and NEXUS Institute, Oslo and Washington, DC, 2012; and P Hondagneu-Sotila and E Avila, "I'm Here, But I'm There": The meanings of Latina transnational motherhood', Gender and Society, vol. 11, no. 5, 1997, pp. $548-571$.

28 See, for example, E Avila, Transnational Motherbood and Fatherhood: Gendered challenges and coping, University of Southern California, Los Angeles, 2008.

29 This is consistent with research on transnational parenthood, in which women migrants are more likely to be treated as 'bad mothers' and fathers as 'heroes'. See Avila, pp. 75-78 and pp. 128-130; and Hondagneu-Sotila and Avila.

30 Avila, Transnational Motherhood and Fatherhood; A Brunovskis and R Surtees, 'Coming Home: Challenges in family reintegration for trafficked women', Qualitative Social Work, 2012; Hondagneu-Sotila and Avila, 'I'm Here, But I'm There'.

31 K Haagsman and V Mazzucato, 'The Quality of Parent-child Relationships in Transnational Families: Angolan and Nigerian migrant parents in the Netherlands', Journal of Ethnic and Migration Studies, vol. 40, no. 11, 2014; A FresnozaFlot, 'Migration Status and Transnational Mothering: The case of Filipino migrants in France', Global Networks, vol. 9, no. 2, 2009; RS Parrenas, 'Long Distance Intimacy: Class, gender and intergenerational relations between mothers and children in Filipino transnational families', Global Networks, vol. 5, no. 4, 2005; M Madianou and D Miller, 'Mobile Phone Parenting: Reconfiguring relationships between Filipina migrant mothers and their left-behind children', New Media \& Society, vol. 13, no. 3, 2011.

32 Graham et al., 'Transnational Families and the Family Nexus'.

33 Nonetheless, prevailing gender norms suggest that expectations of contact from mothers are higher than from fathers. Mothers retain responsibility for nurturing the family despite their breadwinner role overseas. Left-behind children describe greater feelings of abandonment when mothers are not present compared with fathers. See, for example, Graham et al. 'Transnational Families and the Family Nexus'. One study in Mexico found that migrant mother-child relationships depend on the mothers' ability to 'demonstrate emotional intimacy from a distance'; migrant father-child relations correlate with fathers' ability to provide economically. J Dreby, 'Honor and Virtue: Mexican parenting in the transnational context', Gender \& Society, vol. 20, no. 1, 2006, p. 56. Another study concluded that Filipino transnational fathering practices tended not to include transnational communication with children. RS Parrenas, 'Transnational Fathering: Gendered conflicts, distant disciplining and emotional gaps', Journal of Ethnic and Migration Studies, vol. 34, no. 7, 2008, p. 1068. 
a migrant father-evidence that he is fulfilling his paternal role-may aid in soothing the parent/child relationship while he is away. Not being able to remit money because of trafficking meant 'failing' in his paternal role.

Some children were disappointed by their father's 'failure', as one man explained: 'My life is destroyed. ... [My family is] disappointed. My family is almost broken ... it disappointed my eldest son. ... Until now I do not work.' Men, in turn, were stressed about being unable to support their children, as one explained: 'When I came home, I worried much, especially about all the debts ... I came home in failure twice and the second time I brought so much burden. ... I worry so much about my family, my children, my house.'

Some men spoke about being traumatised by their exploitation, inhibiting their ability to behave and interact with these children in healthy ways. ${ }^{34}$ One man described being emotional and easily angered, which took a toll on his children: ' $[I$ was] unstable and shaken. I thought a lot about the costs and the unfortunate events when I was there. I have never experienced something like that before. I didn't know what to feel, actually. I didn't know where to look for help. ... The kids were in shock. I got angry easily.'

Problems emerged in some fathers' relationships with their children because of what the children were told about them in their absence-most commonly that they had not provided for their families. One man described a broken relationship with his children because of rumours that he was irresponsible and had not sent money home to raise them: 'There was a time when my relationship with my children was broken. ... They only heard one side of the story from their family or the community surrounding them ... that I am the kind of person who does not take responsibility, or I am a bad person.' This man's wife became ill while he was trafficked and died shortly after his return. The children were raised by his wife's family who continued to speak badly of him. While he eventually repaired his relationship with one son, his oldest son continues to blame him for what he perceives as neglect and abandonment: 'When there is someone talking about it, my second child would even defend me. ... But my first child would not say anything. He would be listening only, and finally it would be negative. Sometimes when he met me he would be angry.'

\section{Relationships with parents and parents-in-law}

Filial responsibility is critical to both Javanese and Sundanese. Children are expected to pay deference and respect to their parents and provide support and assistance, particularly in old age. ${ }^{35}$ One man broke down in tears over his failure to help his parents: 'I was migrating because I wanted to seek money for my parents' medication, for my parents ...'

Men were both positively and negatively received in their families after return. One man described a warm and uncomplicated homecoming: '[My family] was welcoming. After all, I am their child. Being able to come home safely made them happy. ... I have a poor family but they all live in harmony. That is enough for us. Everybody wants to have many things but we are grateful for our lives and family.'

But others also spoke about their parents' profound sadness and distress when they returned home ill, thin, depressed and stressed. Said one man (married and with children): 'When I told [my parents], they cried. They have a son but their son was beaten by other people.' Said one (young and unmarried) man of his father's reaction: 'Sometimes my father looks so sad looking at me, as I went home skinny ... somehow my parents felt uncertain, they despaired and sometimes they cried.'

Married men had less leeway when it came to parental support; they were expected to return to work and care for their families. By contrast, a number of unmarried men described periods of rest and recovery in their parents' homes and an easy reception from parents and siblings. Said one unmarried man: 'My mother said, "Luckily you came home safely. The most important thing is that you are healthy, that's all."... My brother was

34 Male labour trafficking was 'associated with symptoms of depression, anxiety and post-traumatic stress disorder'. N Pocock, L Kiss, S Oram and C Zimmerman, 'Labour Trafficking among Men and Boys from the Greater Mekong Subregion: Exploitation, violence, occupational health risks and injuries', PLOS ONE, vol. 11, no. 12, 2016, p. 3.

35 N Mulder, Inside Indonesian Society: Cultural change in Java, Pepin Press, Netherlands, 1996, p. 112; A Wilcox-Palmer, 'Situradja: A village in Highland Priangan' in Koentjaraningrat (ed.), Villages in Indonesia, Cornell University Press, New York, 1967, pp. 299-325. 
nice to me. ... [My sister said], "Thank God you are fine. It was not a big deal if you did not get your payment. The important thing is your health.",

Whether married or unmarried, most men described feeling ashamed about their 'failed' migration and returning without money. One man also described feelings of guilt about relying on his parents: 'In the first months, my family helped me. Frankly, I felt sorry because we became a burden to my parents.'

Men were also concerned about how their parents perceived them. One worried that his mother thought that he had been frivolous with his earnings abroad: 'I mostly worried when I met my mother because I did not bring anything home ... I was afraid that she wouldn't believe me and think that I spent my money on something not useful.' In some cases, 'failure' seemed to have lessened men in the eyes of their parents, as one explained: ' $[\mathrm{My}]$ parents now see me as incapable, undeserving. I no longer feel part of the family.'

A complicating feature was that some men behaved negatively, due to stress and trauma, even when encouraged by parents, as one man explained: 'After that negative experience I feel that I got irritated easily. Whenever somebody said something, I'd get upset and emotional. Everything people did was wrong.'

Some parents thought their son was a criminal (equating detention of irregular migrants with their having committed a crime), which, as one man explained, led to being rejected by his family: 'I only met my wife because my family was indifferent. They knew I came from prison. Only my wife still accepted me ... even my own biological parents did not want to accept me at all. ... And other relatives did not comfort me. They stayed away from me.'

Men also navigated differing relations with parents-in-law. Some were supportive, like those of one man who made no issue of his 'failed' migration: 'We have been married for sixteen years; my parents-in-law never intervened with us ... "it's up to you, take care of your business." By contrast, another man, whose wife was working abroad, explained that his parents-in-law were unhappy with him as he had 'failed' at his migration, while their daughter was now supporting him and their family.

\section{Conclusion}

Human trafficking took a substantial toll on the lives of the interviewed men and their families. They struggled not only with financial issues, but also with fractures in their relationships with wives, children and extended family. Moreover, facing blame and criticism from neighbours and friends amplified already strained family relationships. Some men's families were shaken by human trafficking; other families were destroyed.

Supporting trafficked men's recovery and reintegration requires a better understanding of the family and community environment to which they return, in all of its complexity and messiness. It requires thinking beyond the immediacy of economics to disentangle the dynamics at play in men's lives, families and communities. It also requires thinking about how trafficking has profoundly affected not only trafficked men but also their wives, children and extended family. This understanding can be a first step in helping men and their families to develop tools and strategies to cope with what are often stressed and anxious behaviours exhibited by trafficked men during reintegration, and also to work to restore the family relationships that have been damaged by trafficking separations and unfulfilled expectations.

Rebecca Surtees is an anthropologist and senior researcher at NEXUS Institute, a policy and researcher centre based in Washington. Recent research projects include a longitudinal study of reintegration of trafficking victims in Indonesia; a study of reintegration of trafficking victims in the Mekong region; research on the exploitation and trafficking of fishers; studies on victim identification in Indonesia and the Balkans; and research into human trafficking amongst migrants and refugees along the Balkan route. Email: rsurtees@nexusinstitute.net 